\title{
Association Between Seasonal Allergic Rhinitis and Air Pollution, Meteorological Factors, and Grass Pollen Counts in Madrid (1996 and 2009)
}

\author{
Cabrera M¹, Garzón García B², Moreno-Grau S33, Subiza J4 \\ 'Consulta de Alergia Hospital Los Madroños, Brunete, Spain \\ ${ }^{2}$ Unidad de Estadistica, Secretaría Adjunta de Informática, Consejo Superior de Investigaciones Científicas (CSIC), Madrid, Spain \\ ${ }^{3}$ Departamento de Ingeniería Química y Ambiental, Universidad Politécnica de Cartagena, Spain \\ ${ }^{4}$ Clínica Subiza, Madrid, Spain
}

J Investig Allergol Clin Immunol 2019; Vol. 29(5): 371-377

doi: 10.18176/jiaci.0368

\begin{abstract}
Objective: The aim of this study was to assess the relationship between meteorological and pollution-related variables and the symptoms of patients with seasonal allergic rhinitis due to sensitization to grass pollen during 2 different time periods in Madrid, Spain. Methods: Between March 23 and December 31 in 1996 and 2009, we carried out a daily count of grass pollen grains (Burkard spore trap) and recorded the rhinitis symptom scores in 2 groups of patients with a history of seasonal allergic rhinitis ( $n=25$ in 1996 and $n=23$ in 2009). Descriptive statistics of the same variables during the study periods were recorded. Associations between variables were assessed using the paired-samples Wilcoxon test and categorical principal component analysis (CatPCA, SPSS24 package).

Results: The mean symptom score was low in 1996 and moderate in 2009. The 1996 and 2009 CatPCA analysis explained around 66.4\% and $70.5 \%$ of the variance, respectively. The strongest relationships in 1996 were between symptoms and grass pollen counts ( $R=0.55)$ and between temperature and ozone $(R=0.63)$. In 2009 , the association between temperature and pollution-related variables was even stronger than in 1996 (ozone $[R=0.53]$ and $P_{10}[R=0.34]$, with a positive sign in both cases).

Conclusions: The effect of temperature and pollution (mainly ozone, even at lower atmospheric concentrations than in established guidelines for effects on health) may have contributed to the higher seasonal allergic rhinitis symptom score recorded in 2009.

Key words: Grass pollen grains. Pollution. Temperature. Ozone. Categorical principal component analysis.
\end{abstract}

\section{Resumen}

Introducción: El objetivo de este estudio fue evaluar las relaciones de las variables meteorológicas y contaminantes en los síntomas de los pacientes con rinitis alérgica estacional con sensibilización al polen de gramíneas durante dos períodos diferentes en Madrid.

Métodos: Durante el período del 23 de marzo al 31 de diciembre de 1996 y 2009, se realizó un recuento diario de granos de polen de gramíneas (Burkard spore trap) y puntuación de síntomas de rinitis en dos grupos de pacientes ( $n=25$ en 1996 y n= 23 en 2009 ) con historia de rinitis alérgica estacional. Para describir cómo se relacionan las variables, se realizaron estadísticas descriptivas de las mismas variables en los períodos de estudio de 1996 y 2009, contraste no paramétrico pareado de Wilcoxon y un análisis de componentes principales (CatPCA, SPSS24).

Resultados: El valor medio de la puntuación de síntomas en 1996 fue bajo y en 2009 moderado. El análisis CatPCA de 1996 y 2009 explica aproximadamente el 66,4\% y el 70,5\% de la varianza, respectivamente. La relación más fuerte en 1996 fue entre los síntomas y los recuentos de polen de gramíneas $(R=0,55)$, la temperatura y el $\mathrm{O}_{3}(R=0,63)$. En 2009 , la relación entre la temperatura y las variables de contaminación fue incluso mayor que en el período de 1996: $\mathrm{O}_{3}(R=0,53)$ y con PM10 $(R=0,34)$, en ambos casos con un signo positivo. Conclusiones: El efecto de la temperatura y la contaminación (principalmente $\mathrm{O}_{3}$, incluso a concentraciones atmosféricas más bajas que las pautas establecidas sobre sus efectos en la salud), podría contribuir a la mayor puntuación de síntomas de rinitis alérgica estacional observada en 2009.

Palabras clave: Polen de gramíneas. Contaminación. Temperatura. Ozono. Análisis por componentes principales. 


\section{Introduction}

As many as 44 types of pollen coexist in Madrid, Spain, although seasonal allergic rhinitis is produced mainly by 4 specific types: Cupressaceae (January and February), Platanaceae (March and April), Poaceae, and Oleaceae (May and June) [1].

Grass pollen is the most allergenic in the area, and up to $88 \%$ of patients are polysensitized [2]. Thus, most allergy patients in the center of Spain are sensitized to 4 or 5 different types of pollen, thus implying a longer duration of symptoms throughout the year and greater difficulty when applying pharmacological or prophylactic treatment. In the Alergológica 2015 study, the prevalence of rhinitis (all causes) increased from $55.5 \%$ to $62.0 \%(P<.001)$ compared with the previous study (2005), and grass pollen grains were the principal allergen implicated, with prevalence increasing from $34.8 \%$ to $73.7 \%$. In Madrid, this increase was from $61.9 \%$ to $87.1 \%$ [3]. The age range most affected by seasonal allergic rhinitis is 25-34 years. Consequently, the disease mainly affects young adults, although the overall range is very wide, affecting patients of practically any age [3].

Climate change is increasing the length and intensity of the pollen season, with a significant impact on the millions of patients who already have allergies [4]. Increasing temperatures lead to earlier and longer pollen and allergy seasons, with more frost-free days and earlier and longer flowering seasons $[5,6]$. Higher temperatures also increase ozone production, which sensitizes the respiratory tract to allergens [7]. Higher carbon dioxide levels cause greater plant growth, resulting in increased pollen production and increased pollen potency [8]. More fall-winter precipitation further contributes to increased pollen production [9].

The aim of this study was to assess the relationships between meteorological and pollution-related variables and the symptoms of patients with seasonal allergic rhinitis due to sensitization to grass pollen during 2 different time periods in Madrid.

\section{Material and Methods}

During the periods March 23 to December 31, 1996 and March 23 to December 31, 2009, we carried out the following studies:

- Daily grass pollen count using a Burkard collector (Clínica Subiza, Madrid), as previously described [1]. The main pollen season ran from the first date with 10 grains $/ \mathrm{m}^{3}$ on 3 consecutive days until the date of the last 3 consecutive records at the same level.

- Daily measurement of meteorological data (temperature, rain, humidity, wind speed) using data from BarajasMadrid station (National Meteorological Agency).

- Daily measurement of pollution (ozone, $\mathrm{CO}, \mathrm{SO}_{2}, \mathrm{NO}_{2}$, PM10) from the Escuelas Aguirre station (Madrid City Council).

Table. Descriptive Statistics of the Main Variables Analyzed During Both Study Periods: 23 March to 31 December in 1996 and 2009

\begin{tabular}{|c|c|c|c|c|c|c|}
\hline Variables $^{\mathrm{a}}$ & No. valid & Missing & $\begin{array}{l}\text { Mean (SD) Median } \\
\text { (Minimum- Maximum) }\end{array}$ & No. valid & Missing & $\begin{array}{c}\text { Mean (SD) Median } \\
\text { (Minimum-Maximum) }\end{array}$ \\
\hline Symptom score & 284 & 81 & $\begin{array}{c}1.45(1.74) \\
1.00(0.00-8.00)\end{array}$ & 284 & 81 & $\begin{array}{c}2.33(1.34) \\
1.74(0.61-6.61)\end{array}$ \\
\hline Grass pollen counts, grains $/ \mathrm{m}^{3}$ & 284 & 81 & $\begin{array}{c}21.8(57.2) \\
2.00(0.00-552.0)\end{array}$ & 284 & 81 & $\begin{array}{c}8.28(17.9) \\
1.00(0.00-121.0)\end{array}$ \\
\hline $\mathrm{SO}_{2}, \mu \mathrm{g} / \mathrm{m}^{3}$ & 284 & 81 & $\begin{array}{c}17.7(9.25) \\
15.0(6.00-61.0)\end{array}$ & 284 & 81 & $\begin{array}{c}9.87(3.42) \\
9.00(6.00-21.0)\end{array}$ \\
\hline $\mathrm{CO}, \mu \mathrm{g} / \mathrm{m}^{3}$ & 284 & 81 & $\begin{array}{c}13.7(6.71) \\
12.0(5.00-40.0)\end{array}$ & 284 & 81 & $\begin{array}{c}0.40(0.13) \\
0.37(0.19-1.02)\end{array}$ \\
\hline $\mathrm{NO}_{2}, \mu \mathrm{g} / \mathrm{m}^{3}$ & 284 & 81 & $\begin{array}{c}64.2(17.0) \\
61.5(32.0-117.0)\end{array}$ & 282 & 83 & $\begin{array}{c}52.6(14.0) \\
51.0(17.0-96.0)\end{array}$ \\
\hline $\mathrm{PM} 10, \mu / \mathrm{m}^{3}$ & 284 & 81 & $\begin{array}{c}35.2(8.75) \\
34.0(19.0-61.0)\end{array}$ & 128 & 237 & $\begin{array}{c}30.0(10.7) \\
29.0(10.0-60.0)\end{array}$ \\
\hline $\mathrm{O}_{3}, \mu \mathrm{g} / \mathrm{m}^{3}$ & 284 & 81 & $\begin{array}{c}33.7(15.1) \\
34.0(3.00-71.0)\end{array}$ & 284 & 81 & $\begin{array}{c}43.6(17.9) \\
45.0(8.00-82.0)\end{array}$ \\
\hline Temperature, ${ }^{\circ} \mathrm{C}$ & 284 & 81 & $\begin{array}{c}18.1(6.64) \\
17.8(2.50-31.7)\end{array}$ & 284 & 81 & $\begin{array}{c}18.0(7.31) \\
18.1(0.00-29.8)\end{array}$ \\
\hline Humidity, \% & 284 & 81 & $\begin{array}{c}59.0(13.6) \\
55.0(37.0-95.0)\end{array}$ & 284 & 81 & $\begin{array}{c}34.1(19.8) \\
29.0(8.00-95.0)\end{array}$ \\
\hline Wind speed, $\mathrm{m} / \mathrm{s}$ & 284 & 81 & $\begin{array}{c}16.8(6.06) \\
16.0(7.00-39.0)\end{array}$ & 284 & 81 & $\begin{array}{c}14.8(8.70) \\
13.0(0.00-51.0)\end{array}$ \\
\hline Rainfall, $\mathrm{L} / \mathrm{m}^{2}$ & 284 & 81 & $\begin{array}{c}0.87(2.99) \\
0.00(0.00-24.0)\end{array}$ & 284 & 81 & $\begin{array}{c}8.17(26.7) \\
0.00(0.00-209.0)\end{array}$ \\
\hline
\end{tabular}

${ }^{a}$ Significant differences $(P=.000$, nonparametric paired samples Wilcoxon test $)$ were found for all variables except temperature. 
- Daily count of rhinitis symptoms in 2 groups of patients ( $n=25$ in 1996 and $n=23$ in 2009, after completion of daily symptom cards at home) selected on the basis of a history of seasonal allergic rhinitis during the previous 2 years. Each patient was evaluated based on a medical assessment that included a clinical history, clinical examination, and

Rainfalla 1996 vs 2009, L/m²

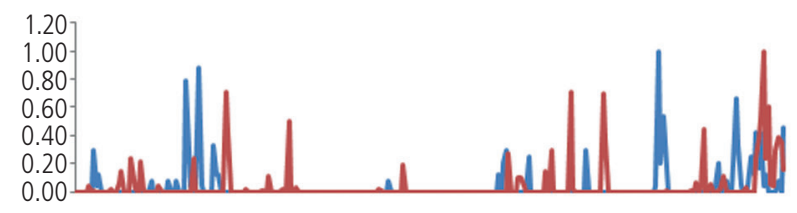

Humidity 1996 vs 2009, \%

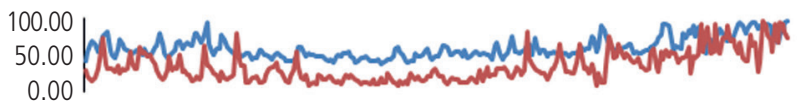

Symptom score $e^{a, b}$ (points) vs grass pollen counts ${ }^{\mathrm{a}}$, grains $/ \mathrm{m}^{3} 1996$

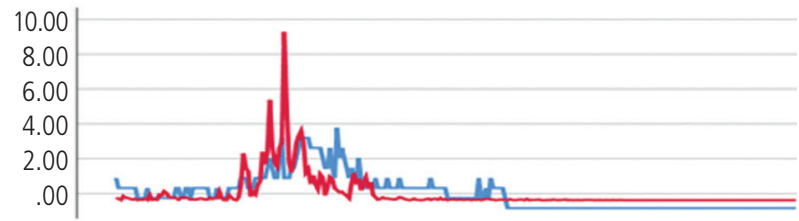

Symptom score $/++$ (points) vs grass pollen counts ${ }^{\mathrm{a}}$, grains $/ \mathrm{m}^{3} 2009$

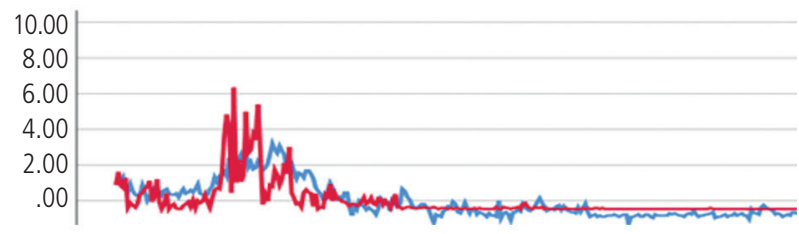

Ozone 1996 vs 2009, $\mu \mathrm{g} / \mathrm{m}^{3}$
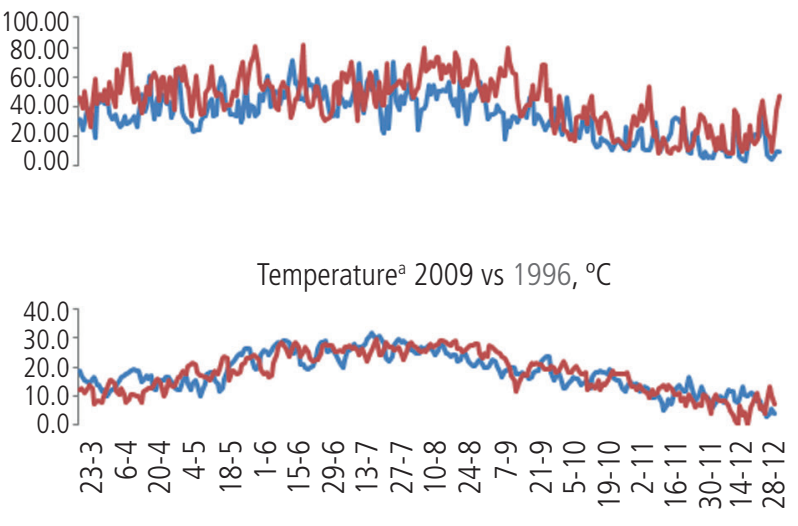

Date

aDaily measurement of all variables.

bMean seasonal allergic rhinitis symptoms score recorded by 25 patients in 1996 and 23 patients in 2009.

Figure 1. Plots of the main variables studied during both time periods 23 March to 31 December in 1996 and 2009. skin prick tests. The mean age of patients was 30.95 (range, 16-47) years, and all patients (100\%) were sensitized to grass pollen (with wheals of $4+[\mathrm{AR}>\mathrm{AH}$ : $\mathrm{AR}=$ resulting area in $\mathrm{mm}^{2}$ : allergen area - saline area]; $\mathrm{AH}$ [histamine area - saline area]) and to Oleaceae, Platanaceae, and Cupressaceae pollen grains $(43.5 \%, 30.4 \%$, and $56.5 \%$, respectively, with smaller wheals: $2+$ to $3+$ ). Two of the patients (2009) were sensitized to Dermatophagoides pteronyssinus and 4 (2009) to cat dander, although the sensitization was not clinically relevant. Nasal symptoms (sneezing, itching, congestion, and rhinorrhea) were assessed in patients clinically sensitized to grass pollens in the previous 2 years. A daily electronic card was completed on a daily basis with the following scale: 0 , absence of symptoms; 1 , mild symptoms; 2, moderate symptoms; and $\geq 3$, severe symptoms.

- Descriptive statistics of the same variables in 1996 and 2009 and a paired-samples Wilcoxon test (SPSS24 package) for non-normally distributed variables in order to enable any significant differences to be seen at the 2 observation points for each of the study variables.

- Categorical principal component analysis (CatPCA, SPSS24 package) [10] to describe associations between variables associated with allergy (grass pollen grains and symptoms). All of the variables were assessed in an initial analysis, and the most important or representative associations were established in the final analysis. This test allowed us to reduce associations between the variables to $2 \mathrm{D}$ and to represent them graphically in both the periods studied. The variance explained by this methodology expresses the ability of the analysis to summarize the relationships between the variables included.

\section{Results}

Total yearly grass pollen counts in 1996 and 2009 were 6588 grains $/ \mathrm{m}^{3}$ and 2556 grains $/ \mathrm{m}^{3}$, respectively (seasonal maximum counts: June 1, with 552 grains $/ \mathrm{m}^{3}$, and May 11, with 121 grains $/ \mathrm{m}^{3}$, respectively). The main pollen seasons lasted from May 13 to July 9 and from May 2 to July 11, respectively.

The Table includes descriptive statistics for all variables for both years, highlighting significant differences $(P=.000)$ based on the paired-samples Wilcoxon test, especially for symptoms (higher score in 2009). The exception was for temperature. This study is limited by the nonavailability of the trend in the variables studied over the years, although the temperature in Madrid has tended to increase over the last 38 years, with temperature increases of $1.4^{\circ} \mathrm{C}$ during May-July from 1979 to 2016 (ie, $0.36^{\circ} \mathrm{C}$ per decade) [11].

Figure 1 shows plots of the main variables studied during both time periods; the samples show that increases in grass pollen grain counts are accompanied by increases in the symptom score (mean value for 1996, low score; mean value for 2009, moderate score).

The CatPCA analysis explains around $66.4 \%$ of the variance in 1996 and $70.5 \%$ of the variance in 2009 . In both cases, these percentages account for the relationships between the variables. 


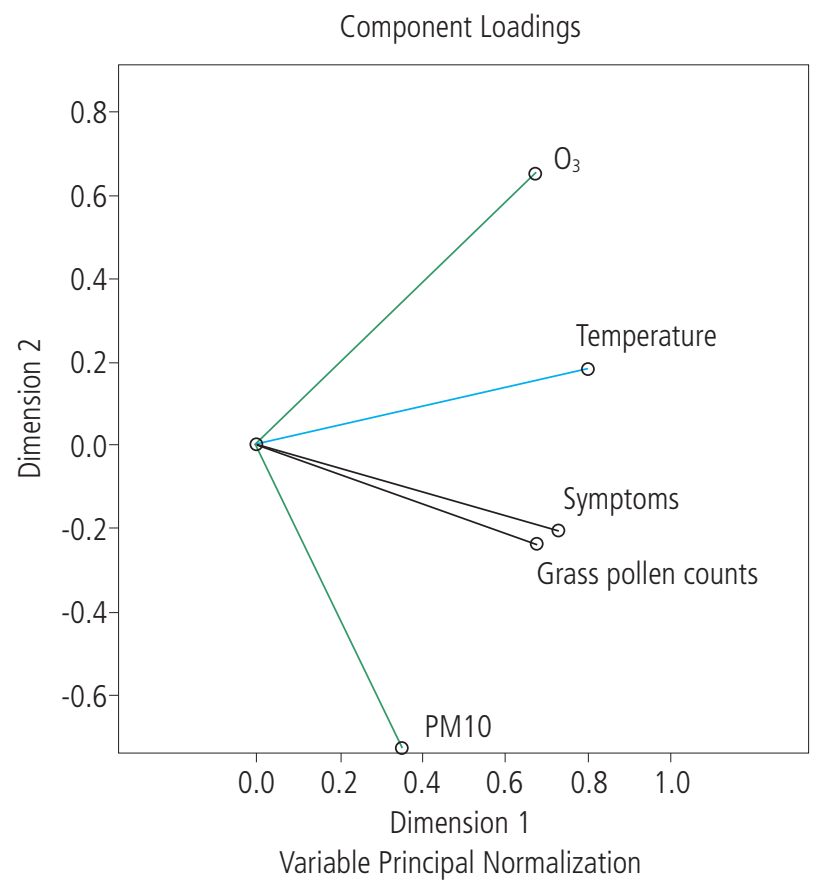

CatPCA analysis explains $66.4 \%$ of the variance

\begin{tabular}{lcccccc}
\hline \multicolumn{6}{c}{ Correlations Transformed Variables } \\
\hline \multicolumn{5}{c}{$\begin{array}{c}\text { Symptoms } \\
\text { pollen counts }\end{array}$} & $\begin{array}{c}\text { Grass } \\
\text { PM10 }\end{array}$ & $\begin{array}{c}\text { Ozone } \\
\text { Tempe- } \\
\text { rature }\end{array}$ \\
\hline $\begin{array}{l}\text { Symptoms } \\
\text { Grass pollen } \\
\text { counts }\end{array}$ & 1.000 & 0.547 & 0.179 & 0.278 & 0.337 \\
PM10 & 0.547 & 1.000 & 0.146 & 0.222 & 0.281 \\
Ozone & 0.179 & 0.146 & 1.000 & -0.097 & 0.334 \\
Temperature & 0.278 & 0.222 & -0.097 & 1.000 & 0.626 \\
\hline
\end{tabular}

Figure 2. CatPCA 1996.

In the 1996 CatPCA analysis, symptoms were related mainly to grass pollen $(\mathrm{R}=0.55)$ and, to a lesser extent, to temperature $(\mathrm{R}=0.38)$ and ozone $(\mathrm{R}=0.28)$; all relationships had a positive sign (Figure 2). With PM10, the correlation coefficient was much lower $(\mathrm{R}=0.18)$. Temperature is related to pollen counts, symptoms, PM10, and ozone (the correlation is particularly strong for ozone, $\mathrm{R}=0.63$ ). Given the position and proximity of the lines on the graph, the variables with the closest association are symptoms and grass pollen counts $(\mathrm{R}=0.55)$ and temperature and ozone $(\mathrm{R}=0.63)$. In both cases, the relationships are positive, meaning that high values in one parameter correspond to high values in the other, ie, higher pollen levels, higher symptoms, higher temperatures, and higher ozone levels. Temperature is also clearly related to symptoms and PM10 ( $\mathrm{R}=0.34$ and $\mathrm{R}=0.33)$; the sign for this relationship is also positive. Consequently, high temperature levels are related to high values for symptoms and PM10. Values for the association between temperature and grass

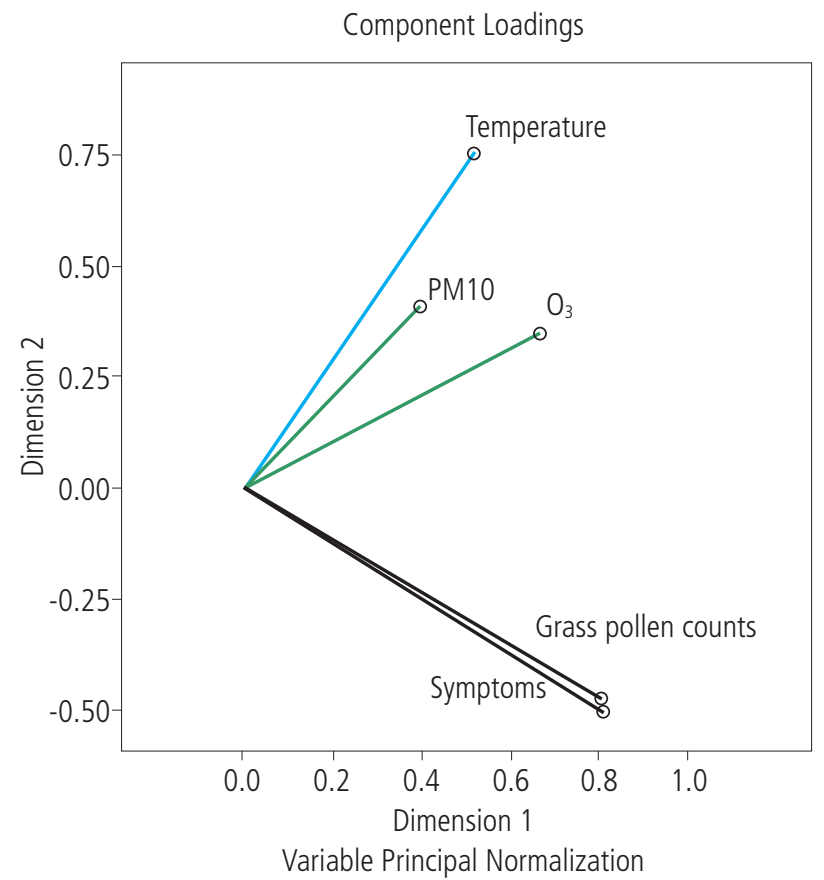

CatPCA analysis explains $70.5 \%$ of the variance

\begin{tabular}{lcccccc}
\hline \multicolumn{6}{c}{ Correlations Transformed Variables } \\
\hline & \multicolumn{1}{c}{$\begin{array}{c}\text { Symptoms } \\
\text { pollen counts }\end{array}$} & $\begin{array}{c}\text { Grass } \\
\text { PM10 }\end{array}$ & $\begin{array}{c}\text { Ozone } \\
\text { Tempe- } \\
\text { rature }\end{array}$ \\
\hline $\begin{array}{l}\text { Symptoms } \\
\begin{array}{l}\text { Grass pollen } \\
\text { counts }\end{array}\end{array}$ & 1.000 & 0.807 & 0.118 & 0.353 & 0.048 \\
PM10 & 0.807 & 1.000 & 0.186 & 0.259 & 0.100 \\
Ozone & 0.118 & 0.186 & 1.000 & 0.056 & 0.359 \\
Temperature & 0.353 & 0.259 & 0.056 & 1.000 & 0.527 \\
\hline
\end{tabular}

Figure 3. CatPCA 2009.

pollen counts are much lower, although the sign continues to be positive $(\mathrm{R}=0.28)$.

Also noteworthy is the weak association between the pollution variables ozone and PM10, which, therefore, occupy distant, almost perpendicular positions on the graph. In addtion, this relationship has a negative sign (high levels of PM10 reduce ozone levels).

The 2009 CatPCA analysis (Figure 3) explains $70.5 \%$ of the variance. The relationship between symptoms and pollen becomes stronger $(\mathrm{R}=0.81)$ and remains positive, as does that of ozone, albeit to a lesser extent $(\mathrm{R}=0.35)$, with both coefficients higher than in 1996.

The difference between the analyses for 2009 and 1996 is in the association between the allergy variables and the rest of the variables (as can be clearly seen in the positions occupied by the variables on the graph). In contrast to the 1996 period, the 2009 variables (symptoms and grass pollen counts) are associated mainly with ozone $(\mathrm{R}=0.35, \mathrm{R}=0.26)$. Therefore, 
ozone is the closest variable in the 2009 graph and is associated with PM10, yet has almost no relationship with temperature (which is distant and almost perpendicular on the graph). The relationship between temperature and pollution variables is even higher than in the 1996 period (ozone $[\mathrm{R}=0.53]$ and PM10 $[\mathrm{R}=0.34]$, with a positive sign in both cases). The pollution variables (ozone and PM10) are still only slightly associated $(\mathrm{R}=0.06)$, although, here, the relationship is still positive.

\section{Discussion}

We found a higher symptom score in the 2009 period, despite lower pollen counts, than in the 1996 period. However, it is important to remember that this was a year with lower humidity, similar temperatures, and higher ozone levels (albeit lower than threshold). Consquently, these factors may have affected the longer duration and intensity of the grass pollen season that year. The specific atmospheric conditions in Madrid in spring, where marked instability leads pollen deposited on the ground to be lifted, may also have contributed.

In southern Spain, the grass pollen season is now longer as a result of rising temperatures [12]; the same is true for the Oleaceae pollen season [13]. The increase in temperature in this geographical area seems to have a positive effect on the intensity of flowering, with longer pollination periods that are often more intense. In this study, the main pollen season in 2009 was 13 days longer than in 1996 . The grass pollen forecast in Madrid is always announced by March. Rainfall from October 1995 to March 1996 in Madrid was twice that of the previous period (October 1994-March 1995), thus leading to a 4-fold higher number of grains in 1996 than in 1995. Furthermore, the Spanish Society of Allergy and Clinical Immunology (SEAIC) estimated that the cumulative concentrations of grass pollen counts in 2009 exceeded 5100 grains $/ \mathrm{m}^{3}$, compared with 4000 grains $/ \mathrm{m}^{3}$ recorded in 2008. Nevertheless, the lower grass pollen counts collected in 2008 were probably due to the cleaner rain effect observed in May, which coincided with the peak grass pollen period (Figure 1), albeit in a more polluted atmosphere and with more allergenic activity, as shown by the higher seasonal allergic rhinitis score.

We suggest that this finding could be associated with the coadjuvant effect of temperature and pollution (mainly ozone), which generates more potent allergens, as well as with the direct relationship between the greater level of atopy in the 2009 group than in the 1996 group. Ozone increases allergenicity (induces larger wheals and flares in skin prick tests) [14], and exposure of Phleum pratense pollen to increasing ozone concentrations (from $100 \mathrm{ppb}$ up to $5 \mathrm{ppm}$ ) results in a significant increase in naturally released pollen cytoplasmic granules, which also contain allergens [15].

Pollution is a possible cause of oxidative stress, and this stress is responsible for the higher prevalence of seasonal allergic rhinitis, which intensifies in activity as a defense from environmental pollution, thus strengthening allergenicity [16]. Pollutants such as $\mathrm{SO}_{2}, \mathrm{NO}_{2}$, and ozone can alter the allergenic proteins of pollen $[16,17]$.

Ozone is a pollutant that usually reaches higher values in areas far from the sources of emission, that is, in semiurban and rural areas. The atmospheric conditions present in heat waves favor the formation of tropospheric ozone from precursors [18]. During the summer, the excessively high temperature in Madrid (higher than the threshold of $36.5^{\circ} \mathrm{C}$ ) coincides with the days on which the population must be warned about high concentrations of ozone (higher than the threshold of $180 \mu \mathrm{g} / \mathrm{m}^{3}$ ) [18]. These thresholds were not exceeded in 2009 , although mean annual values tended to increase [19]. In Madrid in 2017, the number of times the ozone threshold was exceeded ( $>25$ times) was recorded in the 2011-2017 report [20]. As ozone is a secondary pollutant, the measures adopted were aimed at reducing the emission of precursors, mainly NOx and volatile organic compounds [18]. In a recent report from Ecologistas en Acción (2018), 2 of the stations measured high ozone values in winter that were similar to those recorded in spring in the same places (San Agustín de Guadalix and Puerto de la Morcuera), namely, 70 and $80 \mu \mathrm{g} / \mathrm{m}^{3}$ [21].

With regard to photochemical pollutants or the synergistic effect of ultraviolet radiation on pollutants, study of the effects of UV-B rays and ozone shows that the pollen tube was shortened considerably, more than by the stress itself, despite low levels of ozone [22].

Differences have been found in the allergenicity of pollens from groups of trees of the same species and grass pollen, which, although relatively close in terms of taxonomy, are found in areas with different pollution levels (city/countryside) and temperatures (valley/mountain) [23]. In Spain in 2002, Armentia et al [23] reported that the grass pollen in rural areas of the province of Valladolid was less damaged than the same species in urban areas, where grass pollen is subject to a polluted environment, repeated mowing that lets very few spikes flourish, and pesticides applied by local authorities [23]. In 2007, Feo-Brito et al [24] reported that the air pollution levels in Puertollano (high pollution levels) were associated with a greater risk of asthma symptoms in pollen-allergic asthmatic patients than in a similar group from Ciudad Real (lower pollution levels) [24]. The largest contribution was by ozone, especially in Puertollano [24]. In 2007 and 2010, Mur Gimeno et al [25] and Feo-Brito et al [26] reported that pollen-allergic asthmatics in Puertollano presented poorer clinical progress and became decompensated earlier than those from Ciudad Real, and that this could be due to air pollution. Consequently, urbanization and high levels of vehicle emissions induce more symptoms of bronchial obstruction (in particular bronchial asthma) in people living in urban areas than in those living in rural areas.

In the eastern United States and Europe, the highest regional ozone levels are recorded when a slow-moving, highpressure system develops in summer. This is when the days are longest, when solar radiation is most direct (the solar zenith angle is lower), and air temperatures are high. As the slowmoving air in the shallow boundary layer passes over major metropolitan areas, precursor concentrations rise; as the air slowly flows around the high-pressure system, photochemical production of ozone occurs at peak rates [27]. We suggest that high temperatures in Madrid, even with low levels of ozone concentrations (which was higher 13 years later), could be a factor that has contributed to the increase in symptoms even at lower grass pollen counts in 2009 than in 1996. 
Ozone levels are mostly higher in rural areas than in cities. Ozone is degraded by NO, which is also involved in its formation. This degradation occurs more often in cities than in rural areas, because there is more NOx in cities. For this reason, ozone concentrations are higher in rural areas than in cities [27].

According to the review of evidence on health aspects of air pollution in the REVIHAAP Project (Technical Report) (2013) [28], the European threshold of $180 \mu \mathrm{g} / \mathrm{m}^{3}$ for informing the population may thus not be viewed as an effective threshold value under which absolutely no one will experience any effect at all. However, the World Health Organization (WHO) postulated that the effects of concentrations lower than $200 \mu \mathrm{g} / \mathrm{m}^{3}$ will be limited in severity and will only prevail in less than $5 \%$ of the total population [29]. Warning the whole population at lower concentration levels is therefore not advised. As such, the threshold values can be considered a sliding scale, and - albeit somewhat artificially — it is possible to talk about a mild response at (hourly mean) concentrations of $180-240 \mu \mathrm{g} / \mathrm{m}^{3}$, a moderate response at $240-360 \mu \mathrm{g} / \mathrm{m}^{3}$, and a severe response above $360 \mu \mathrm{g} / \mathrm{m}^{3}[28,29]$. The review concludes that a considerable amount of new scientific information on the adverse health effects of particulate matter, ozone, and $\mathrm{NO}_{2}$ observed at levels commonly present in Europe in recent years [28]. This new evidence supports the scientific conclusions of the WHO air quality guidelines, last updated in 2005, and indicates that, in some cases, the effects occur at air pollution concentrations lower than those serving to establish these guidelines [29].

Pollution particles also contain diesel exhaust particles. At present, $70 \%$ of all particles and $90 \%$ of those $<5 \mu \mathrm{m}$ (respirable particles) are produced from its combustion, which induces important biological changes, such as a more marked $\mathrm{T}_{\mathrm{H}} 2$ response [30,31].

The rising frequency of obstructive respiratory diseases during recent years, in particular allergic asthma, can be partially explained by changes in the environment, with the increasing presence in the atmosphere of chemical triggers (particulate matter and gaseous components such as $\mathrm{NO}_{2}$ and ozone) and biologic triggers (aeroallergens). Consequently, measures need to be taken to mitigate the future impact of climate change and global warming [32]. Over the last 50 years, the earth's temperature has risen markedly, likely because of growing concentrations of anthropogenic greenhouse gas [32]. For this reason, it is important to emphasize to patients that climate change is increasing exposure to allergens and suggest what they can do to minimize their exposures and thus reduce allergy and asthma symptoms, such as checking pollen levels frequently. In Spain, patients can sign up for free alerts from the Spanish Society of Allergy and Clinical Immunology Aerobiology Network. For patients with asthma, it is important to check ozone levels.

\section{Conclusions}

The effect of temperature and pollution (mainly ozone, even at lower atmospheric concentrations than those established in guidelines about its effects on health) could contribute to the higher seasonal allergic rhinitis symptom score observed in 2009.
We highlight the need to continue research into the impact of these changes and into strategies and policies to reduce greenhouse gas emissions and air pollution.

\section{Funding}

The authors declare that no funding was received for the present study.

\section{Conflicts of Interest}

The authors declare that they have no conflicts of interest.

\section{Previous Presentation}

This study was presented at Simposio Internacional de Aerobiología, Contaminación y Cambio Climático, 26-28 October 2017, Murcia, Spain.

\section{References}

1. Subiza J, Jerez M, Jiménez JA, Narganes MJ, Cabrera M, Varela $S$, et al. Allergenic pollen pollinosis in Madrid. J Allergy Clin Immunol. 1995 Jul;96(1):15-23.

2. Subiza J, Feo Brito F, Pola J, Moral A, Fernández J, Jerez M, et al. Pólenes alergénicos y polinosis en 12 ciudades españolas. Rev Esp Alergol Inmunol Clin. 1998;13:45-8.

3. Ojeda $P$, Sastre J, Olaguibel JM, Chivato $T$, investigators participating in the 100 National Survey of the Spanish Society of Allergology and Clinical Immunology 101 Alergológica 2015. Alergólogica 2015: A National Survey on Allergic Diseases 102 in the Adult Spanish Population. Investig Allergol Clin Immunol. 2018;103 Jun; 28(3):151-64.

4. D'Amato M, Cecchi L, Annesi-Maesano I, D'Amato G. News on Climate Change, Air Pollution, and Allergic Triggers of Asthma. J Invest Allergol Clin Immunol. 2018;28(2):91-7.

5. Clot B. Trends in airborne pollen: an overview of 21 years of data in Neuchatel (Switzerland). Aerobiologia. 2003;19:22734.

6. Van Vliet A, Overeem A, de Groot R, Jacobs A, Spieksma FTM. The influence of temperature and climate change on the timing of pollen release in the Netherlands. Int J Climatol. 2002:22:1757-67.

7. Meleux F, Solmon F, Giorgi F. Increase in summer European ozone amounts due to climate change. Atmospheric Environment. 2007;41(35):7577-87.

8. Bazzaz FA. The response of natural ecosystems to the rising global CO2 levels. Annu Rev Ecol Syst. 1990;21:167-96.

9. Subiza J, Masiello JM, Subiza JL, Jerez M, Hinojosa M, Subiza E. Prediction of annual variations in atmospheric concentrations of grass pollen. A method based on meteorological factors and grain crop estimates. Clin Exp Allergy. 1992;22(5):540-6.

10. Jolliffe IT. Principal Component Analysis, Series: Springer Series in Statistics, 2nd ed., Springer, NY, 2002, XXIX, 487 p. 28 illus. ISBN 978-0-387-95442-4.

11. Rodríguez V, Kilimajer J, Craciunesco C, Narganes MJ, Cabrera M, Subiza J. Madrid, 38 years of pollen observation: Poaceae pollen counts in a changing weather. Allergy. 2018;73(S105):700.

12. García-Mozo H, Oteros JA, Galán C. Impact of land cover changes and climate on the main airborne pollen types in 
Southern Spain. Sci Total Environ. 2016 Apr 1; 548-549:2218.

13. Galera MD, Elvira-Rendueles B, Moreno JM, Negral L, RuizAbellón MC, García-Sánchez A, et al. Analysis of airborne Olea pollen in Cartagena (Spain). Sci Total Environ. 2018 May 1;622-3:436-45.

14. Beck I, Jochner S, Gilles S, McIntyre M, Buters JT, Schmidt-Weber $C$, et al. High environmental ozone levels lead to enhanced allergenicity of birch pollen. PLoS One. 2013;8:e80147.

15. Rogerieux F, Godfrin $D$, Sénéchal $H$, Motta $A C$, Marlière $M$, Peltre $G$, et al. Modifications of Phleum pratense grass pollen allergens following artificial exposure to gaseous air pollutants (O(3), $\mathrm{NO}(2)$, $\mathrm{SO}(2))$. Int Arch Allergy Immunol. 2007;143(2):127-34.

16. Suárez-Cervera $M$, Castells $T$, Vega-Maray $A$, Civantos $E$, del Pozo V, Fernández-González D, et al. Effects of air pollution on cup a 3 allergen in Cupressus arizonica pollen grains. Ann Allergy Asthma Immunol. 2008 Jul;101(1):57-66.

17. D'Amato G. Urban air pollution and plant-derived respiratory allergy. Clin Exp Allergy. 2000 May;30(5):628-36.

18. Querol X, Alastuey A, Gangoiti G, Perez N, Lee HK, Heeram R, et al. Eun Phenomenology of summer ozone episodes over the Madrid Metropolitan Area, central Spain. Atmos Chem Phys. 2018;18:6511-33.

19. Calidad del Aire Madrid 2009. Dirección General de Calidad, Control y Evaluación Ambiental. Servicio de Calidad del Aire. Available at:http://www.mambiente.munimadrid.es/opencms/ export/sites/default/calaire/Anexos/MEMORIA_2009.pdf Accessed December 2018.

20. Ministerio Para la Transición Ecológica. Evaluación de la Calidad delAire en EspañaAño 2017. Available at: https://www.miteco. gob.es/es/calidad-y-evaluacion-ambiental/temas/atmosferay-calidad-del-aire/informeevaluacioncalidadaireespana2017_ tcm30-481655.pdf Accessed December 2018.

21. Ecologistas en acción. La contaminación por ozono en España durante 2018. Available at: https://www.ecologistasenaccion. org/wp-content/uploads/2018/10/informe-ozono-2018.pdf Accessed December 2018.

22. Feder WA. Reduction in tobacco pollen germination and tube elongation, induced by low levels of ozone. Science 1968 Jun 7;160(832):1122.

23. Armentia A, Lombardero M, Callejo A, Barber D, Martin Gil FJ, Martin-Santos JM, et al. Is Lolium pollen from an urban environment more allergenic than rural pollen? Allergol Immunopathol (Madr). 2002 Jul-Aug;30(4):218-24.

24. Feo Brito F, Mur Gimeno P, Martínez C, Tobías A, Suárez L, Guerra $F$, et al. Air pollution and seasonal asthma during the pollen season. A cohort study in Puertollano and Ciudad Real (Spain). Allergy. 2007 Oct;62(10):1152-7.

25. Mur Gimeno P, Feo Brito F, Martínez C, Tobías A, Suárez L, Guerra $F$, et al. Decompensation of pollen-induced asthma in two towns with different pollution levels in La Mancha, Spain. Clin Exp Allergy. 2007 Apr;37(4):558-63.

26. Feo Brito $F$, Mur Gimeno $P$, Carnés J, Fernández-Caldas E, Lara P, Alonso AM, et al. Grass pollen, aeroallergens, and clinical symptoms in Ciudad Real, Spain. J Investig Allergol Clin Immunol. 2010;20(4):295-302.

27. Seinfeld JH, Pandis SN. Atmospheric Chemistry and Physics: From Air Pollution to Climate Change.New York: John Wiley and Sons INC. (ISBN 047117815 2).

28. WHO Regional Office for Europe. Review of evidence on health aspects of air pollution - REVIHAAP Project: Technical Report [Internet]. Copenhagen: WHO Regional Office for Europe; 2013.

29. WHO (2006) Air Quality Guidelines. Global update 2005. World Health Organization 2006. http://www.euro.who.int/ Document/E90038.pdf

30. Diaz-Sanchez D, Tsien A, Fleming J, Saxon A. Combined diesel exhaust particulate and ragweed allergen challenge markedly enhances human in vivo nasal ragweed-specific $\lg \mathrm{E}$ and skews cytokine production to a T helper cell 2-type pattern. J Immunol. 1997;158:2406-13.

31. Knox RB, Suphioglu C, Taylor P, Desai R, Watson HC, Peng JL, et al. Major grass pollen allergen Lol $p 1$ binds to diesel exhaust particles: implications for asthma and air pollution. Clin Exp Allergy. 1997;27:246-51.

32. D'Amato M, Cecchi L, Annesi-Maesano I, D Amato G. News on Climate Change, Air Pollution, and Allergic Triggers of Asthma. J Investig Allergol Clin Immunol. 2018;28(2):91-7.

\section{- Manuscript received October 2, 2018; accepted for publication December 19, 2018.}

\section{- Martha Cabrera Sierra}

Servicio de Alergia

Hospital los Madroños

Carretera M-501, Km 17,9

28690 Brunete, Madrid

E-mail: marthacs65@gmail.com 